\title{
ОХОРОНА АВТОРСЬКИХ ПРАВ НА КІНЕМАТОГРАФІЧНИЙ ТВІР ЗА БЕРНСЬКОЮ КОНВЕНЦІЕЮ ПРО ОХОРОНУ ЛІТЕРАТУРНИХ I ХУДОЖНІХ ТВОРІВ ТА ВСЕСВІТНЬОЮ КОНВЕНЦІЕЮ ПРО АВТОРСЬКЕ ПРАВО
}

Постановка проблеми. В останні десятиліття спостерігається стрімкий розвиток кінематографічної індустрії. Водночас одним із пріоритетних завдань залишається вдосконалення національної системи охорони прав інтелектуальної власності на кінематографічний твір. В цьому контексті вагомого значення набуває виокремлення ключових міжнародних стандартів охорони прав інтелектуальної власності у кінематографічній сфері та усунення прогалин у правовому регулюванні наведених відносин е національному законодавстві. Усі вищезазначені фактори вплинули на вибір теми здійснюваного дослідження.

Аналіз останніх досліджень i публікацій. Розкриттю змісту основних положень Бернської конвенції про охорону літературних і художніх творів, а також втіленню та розвитку іiі принципів у Всесвітній конвенції про авторське право присвячено монографію професора В.С. Дроб'язка «Історичні й теоретичні аспекти Бернської конвенції про охорону літературних і художніх творів». До того ж проблему конвенційної охорони авторських прав частково проаналізовано у працях К.О. Афанасьєвої, Т.М. Вахонєвої, I.I. Дахно, Т.О. Коваленко.

Метою статті є виявлення ключових аспектів охорони авторських прав на кінематографічний твір на підставі аналізу відповідних положень Бернської конвенції про охорону літературних і художніх творів та Всесвітньої конвенції про авторське право.

Виклад основного матеріалу. На міжнародному рівні кінематографічний твір вперше було визнано об'єктом правової охорони у Бернській конвенції про охорону літературних і художніх творів [1] від 1886 року внаслідок перегляду положень останньої під час Берлінської конференції у 1908 році, адже саме на початку XX століття відбувалося становлення кіномистецтва як самостійного виду творчості, у зв'язку з чим сформувався самостійний об’єкт авторського права - кінематографічний твір. Перегляд основних положень Конвенції був зумовлений серед низки причин необхідністю забезпечення належного нормативно-правового захисту авторів кінематографічних творів. Як наслідок, «берлінський текст» Конвенції розширив перелік об'єктів авторського права, зокрема, шляхом включення до нього кінематографічних творів. Україна приєдналась до Бернської конвенції про охорону літературних і художніх творів 31 травня 1995 року [2].

I.I. Дахно відзначає такі ключові стандарти з охорони авторських прав, встановлені Бернською конвенцією про охорону літературних і художніх творів: 
1) охорона моральних (немайнових) прав авторів;

2) чинність авторських прав впродовж усього життя відповідних авторів та п'ятдесяти років після їх смерті;

3) заборона на виконання будьяких формальностей для набуття авторських прав;

4) низка положень щодо охорони авторських прав у країнах, що розвиваються [3, с. 155-156].

Серед низки літературних та художніх творів, які підлягають охороні, у ст. 2 (1) Бернської конвенції відзначено кінематографічні твори, до яких прирівнюються твори, виражені способом, аналогічним кінематографіiі. Варто наголосити на тому, що стосовно кінематографічних творів можуть застосовуватись як основні положення й принципи зазначеної Конвенції, так і низка спеціальних положень, які безпосередньо вирішують питання охорони кінематографічних творів та творів, які використовуються під час їх створення [4, с. 21].

Аналіз спеціальних положень доцільно розпочати зі звернення до порядку охорони авторських прав на кінематографічний твір. Насамперед зазначимо, що гарантований Конвенцією мінімальний строк охорони прав авторів становить весь час життя автора й п'ятдесят років після його смерті. Згідно зі ст. 7 (2) Бернської конвенції про охорону літературних і художніх творів для кінематографічних творів, країни Союзу вправі передбачити, що термін охорони закінчується через п'ятдесят років після того, як твір за згодою автора було зроблено доступним для загального відома, або, якщо протягом п'ятдесяти років з часу створення такого твору ця подія не настане, термін охорони закінчується через п'ятдесят років після створення твору.

Положення про можливість встановлення особливого терміну охорони кінематографічного твору було закріплено внаслідок Стокгольмського перегляду Конвенції у 1967 році.
Одним із ключових аргументів на користь внесення відповідних змін слугував той факт, що використання дати смерті автора (або останнього з живих співавторів, оскільки фільми майже завжди $є$ творами, створеними у співавторстві) як дати початку строку охорони було б важким для практичного застосування [5, с. 60]. Особливо з огляду на той факт, що перелік відповідних авторів у країнах-членах Союзу є неоднаковим. До того ж у деяких країнах авторство визнається за виробником фільму, який переважно є юридичною особою [5, c. 31].

Особливості правового режиму кінематографічного твору враховано під час врегулювання Конвенцією порядку визначення осіб, наділених авторськими правами на кінотвір. Важливість вироблення єдиної концепції зумовлювалась тим фактом, що законодавства різних країн дотримувались відмінних підходів до вирішення питання авторства кінематографічного твору. Узагальнивши відповідні підходи, В.С. Дроб'язко виокремив такі теорії авторства кінематографічного твору:

1) система «авторського права на фільм», яка визнає як володільця авторського права тільки виробника фільму;

2) система, за якою фільм розглядається як спільний твір кількох авторів, що роблять свій художній внесок, та яка передбачає, що виробник зобов'язаний одержати повноваження у цих авторів, щоб мати можливість використати твір;

3) система, названа «відступленням прав за законом», яка розглядає кінематографічний твір як спільний твір кількох авторів, але при цьому законодавство країн презюмує контракт із виробником, який містить перевідступлення прав на використання фільму [5, с. 51].

3 огляду на відмінності у врегулюванні питання авторства кінотвору між законодавствами держав-учасниць 
Конвенції в пп. (а) п. 2 ст. 14bis останньої закріплено правило, згідно 3 яким визначення осіб, що мають авторські права на кінематографічний твір, зберігається за законодавством країни, в якій витребується охорона, тобто положення Бернської конвенціï сформульовані таким чином, що дають змогу національним законодавствам не тільки встановлювати різні положення про перехід прав автора до виробників аудіовізуальних творів, зокрема передбачати різні презумпції про перехід авторських прав, але й визнавати початковими власниками прав на аудіовізуальний твір його виготовлювачів, в тому числі юридичних осіб [6].

Крім того, доволі часто кінематографічний твір створюється на підставі переробки чи іншого використання творів, що $є$ самостійними об'єктами авторського права. Отже, постає необхідність забезпечення належної охорони прав авторів таких творів. В цьому контексті заслуговують на увагу положення ст. 14 Бернської конвенції, сформульовані під час Стокгольмського перегляду (1967 рік) останньої. В ній, зокрема, зазначено, що автори літературних і художніх творів мають виключне право дозволяти кінематографічну переробку і відтворення своїх творів та поширення перероблених або відтворених таким способом творів; публічний показ і виконання перероблених або відтворених таким способом творів i повідомлення їх по проводах для загального відома. До того ж закріплено, що переробка в будь-яку іншу художню форму кінематографічної постановки, похідної від літературного або художнього твору, незалежно від дозволу його автора вимагає дозволу автора оригінального твору.

Щодо кінотвору, похідного від того чи іншого літературного чи художнього твору, то у ст. 14 bis закріплено правило, згідно з яким без збитку авторським правам на будь-який твір, який міг би бути перероблений або відтворений, кінематографічний твір підлягає охороні як оригінальний твір. Отже, особа, яка має авторське право на кінематографічний твір, користується такими ж правами, як і автор оригінального твору, включаючи права, передбачені у ст. $14 \mathrm{Koн-}$ венції.

Специфіку правового режиму кінематографічного твору в процесі Стокгольмського перегляду (1967 рік) Бернської конвенції було враховано під час формулювання визначення поняття «випущені у світ твори». Під останніми, згідно зі ст. 3 (3) Конвенціi, запропоновано розуміти твори, випущені за згодою їхніх авторів, який би не був спосіб виготовлення примірників, за умови, якщо ці примірники випущені в обіг у кількості, здатній задовольнити розумні потреби публіки, беручи до уваги характер твору. До того ж зазначено, що не $€$ випуском у світ представлення драматичного, музично-драматичного або кінематографічного твору, виконання музичного твору, публічне читання літературного твору, повідомлення по проводах або передача в ефір літературних або художніх творів, показ твору мистецтва й спорудження твору архітектури.

Серед положень Бернської конвенції, присвячених охороні прав на кінематографічний твір, варто також відзначити пп. b п. 2 ст. 14bis, згідно 3 яким у країнах Союзу, законодавство яких включає у число осіб, що мають авторське право на кінематографічні твори, авторів, що зробили внесок у його створення, ці автори, якщо вони зобов'язалися зробити такий внесок, не вправі за відсутності будь-якої протилежної або особливої умови виступати проти відтворення, поширення, публічного показу й виконання, повідомлення по проводах для загального відома, передачі в ефір або будь-якого іншого публічного повідомлення твору, а також субтитрування і дублювання його тексту, тобто Бернська конвенція встановлює презумпцію 
передачі авторами своїх прав на кінематографічний твір його виробникові. Водночас необхідно зауважити, що зазначена презумпція діє лише за умови відсутності інших домовленостей з авторами і лише щодо тих категорій авторів, які зазначені в національних законодавствах як автори кінематографічного твору [6].

Таким чином, саме прийняття Бернської конвенції про охорону літературних і художніх творів заклало підвалини міжнародної системи охорони авторських прав, зокрема, у кінематографічній сфері. Щоправда, протягом тривалого часу вона залишалась неприйнятною для низки країн, зокрема, тому, що іiі рівень мінімальної охорони був досить високим порівняно з відповідними національними законодавствами чи не відповідав їхній системі авторського права [7, с. 29].

Як наслідок, на міжурядовій конференції в Женеві у вересні 1952 року було прийнято Всесвітню конвенцію про авторське право [8], яка набула чинності у вересні 1955 року. Як зазначає В.С. Дроб'язко, остання була створена, щоб надати низці країн, зокрема тодішньому СРСР і США, можливість приєднатися до багатостороннього міжнародного договору про охорону авторського права та забезпечити охорону авторського права на світовому рівні, тоді як розрив між багатосторонніми американськими договорами та європоцентричною Бернською конвенцією загрожував загальній меті світової охорони [7, с. 29]. Україна приєдналась до Всесвітньої конвенції про авторське право 23 грудня 1993 року [9].

Стаття 1 Конвенції зобов'язує країн-учасниць вжити усіх заходів, необхідних для забезпечення достатньої та ефективної охорони прав авторів і всіх інших власників авторських прав на літературні, наукові й художні твори, в тому числі твори кінематографічні. Як правильно відзначає T.M. Вахонєва, зазначеною нормою не закріплюються конкретні заходи, які мають застосовуватись для досягнення цього результату. Передбачається, що кожна держава сама повинна визначити, наскільки доцільне застосування цивільно-правових норм, а також використання адміністративного впливу або застосування кримінального законодавства для охорони авторських прав [10, с. 17].

Вибравши своїм основним правилом охорони власників авторських прав принцип національного режиму, Всесвітня конвенція про авторське право містить низку матеріально-правових норм, наявність яких забезпечує необхідний мінімум охорони авторських прав у країнах-учасницях [11, с. 41]. Йдеться, зокрема, про ч. 2 ст. IV Конвенції, згідно з якою строк охорони творів, на які поширюється іiі дія, не може бути коротшим за період, що охоплює час життя автора й двадцять п'ять років після його смерті, на відміну від Бернської конвенції про охорону літературних і художніх творів, термін охорони, встановлений якою, охоплює весь час життя автора й п'ятдесят років після його смерті.

По-іншому у Всесвітній конвенції про авторське право врегульовано також питання набуття правової охорони. Так, у ст. III Конвенції зазначено, що будь-які формальності, якщо такі визначені у внутрішньому законодавстві держави-учасниці Конвенціі як неодмінна умова охорони авторського права (депонування примірників, реєстрація, застереження про збереження авторського права, нотаріальні посвідчення, сплата зборів, виготовлення або випуск у світ примірників твору на території зазначеної держави), вважаються виконаними щодо всіх творів, які охороняються на підставі цієї Конвенції і які вперше випущені у світ поза територією цієї держави, і автори яких не є їі громадянами, якщо з першого випуску у світ цих творів усі їхні примірники, випущені з дозволу автора або будь-якого 
іншого власника його прав, носитимуть знак «С» із зазначенням імені власника авторського права й року першого видання. Водночас Конвенція не забороняє будь-якій договірній державі вимагати додержання формальностей або інших умов для одержання та здійснення авторських прав на твори, вперше випущені у світ на iii території, або на твори іiі громадян незалежно від місця випуску їх у світ.

Згідно з п. 2 ст. 5 Бернської конвенції про охорону літературних і художніх творів, користування авторськими правами та їх здійснення не пов'язані з виконанням будь-яких формальностей; таке користування й здійснення не залежать від існування охорони у країні походження твору. В цьому ж пункті зазначено, що, крім установлених цією Конвенцією положень, обсяг охорони, як і засоби захисту, що забезпечують автору охорону його прав, регулюється виключно законодавством країни, в якій виникає потреба в ній. Таким чином, Бернська конвенція не пов'язує виникнення авторських прав на твір з дотриманням тих чи інших формальностей (реєстрація, депонування примірників тощо).

Щодо колізій, які можуть виникати на практиці з огляду на одночасне існування вищезазначених конвенцій, то варто зауважити, що режим охорони авторських прав, викладений у Всесвітній конвенції про авторське право, слугує доповненням уже чинних міжнародних систем охорони, не зачіпаючи їх, про що зазначено у Преамбулі розглядуваної Конвенціi. Згідно з п. 1 ст. XVIII Всесвітньої конвенції, вона ні в чому не зачіпає постанови Бернської конвенції про охорону літературних і художніх творів і належності до Спілки, утвореної цією Конвенцією.

Задля зміцнення наявної міжнародної системи охорони авторських прав державами-учасницями Всесвітньої конвенції було також прийнято Декларацію щодо ст. XVIII Конвенції. Згідно $з$ нею, твори, країною похо- дження яких, згідно з положеннями Бернської конвенції, є держава, яка вийшла після 1 січня 1951 року зі складу Міжнародної спілки, утвореної цією Конвенцією, не користуватимуться в країнах Бернської спілки охороною, яку надає Всесвітня конвенція з авторського права. В Декларації також закріплено, що Всесвітня конвенція з авторського права не підлягає застосуванню у відношеннях між країнами, пов'язаними Бернською конвенцією, в тому, що стосується охорони творів, країною походження яких, згідно з положеннями Бернської конвенції, є одна з країн Міжнародної спілки, утвореної цією Конвенцією.

Висновки. Підсумовуючи, наголошуємо на тому, що Бернська конвенція про охорону літературних і художніх творів та Всесвітня конвенція про авторське право закріплюють ключові міжнародні стандарти охорони й захисту авторських прав, зокрема, у кінематографічній сфері. Водночас варто погодитися з К.О. Афанасьєвою в тому, що положення Всесвітньої конвенції про авторське право мають більш загальний характер та відрізняються від положень Бернської конвенції про охорону літературних i художніх творів підходами до низки принципових питань [12, с. 38]. Відповідне зауваження вбачається обгрунтованим щодо кінематографічного твору, адже, на відміну від Всесвітньої конвенції про авторське право, яка обмежується лише визнанням кінотвору об'єктом охорони авторським правом, Бернська конвенція містить низку спеціальних положень, присвячених врегулюванню порядку реалізації та захисту авторських прав на кінотвір.

У статті розкрито основні аспекти охорони авторських прав на кінематографічний твір на підставі аналізу положень Бернської конвенції про охорону літературних $i$ художніх творів ma Всесвітньої конвенціі про авторське 
право. Звернено увагу на те, що саме Бернська конвенція заклала підвалини міжнародної системи охорони авторських прав на кінотвір шляхом включення останнього до переліку об’єктів авторського права за результатами Берлінської конференції у 1908 році. Відзначено той факт, що стосовно кінематографічних творів можуть застосовуватись не лище основні приниипи зазначеної Конвенції, але й низка спеціальних положень, які безпосередньо вирішують питання охорони останніх. Так, особливості правового режиму кінематографічного твору враховано під час урегулювання Конвенцією таких питань: строк охорони кінотвору; порядок визначення осіб, наділених авторськими правами на нього; порядок передачі авторами своїх прав на кінематографічний твір його виробникові.

Зазначено, що з огляду на високий порівняно з відповідними національними законодавствами рівень мінімальної охорони, встановлений Бернською конвенцією, протягом тривалого часу вона залишалась неприйнятною для низки країн. Як наслідок, задля забезпечення необхідних передумов для подальшого розширення міннародного співробітництва у сфері охорони авторського права на міжурядовій конференції в Женеві у вересні 1952 року було прийнято Всесвітню конвеничію про авторське право.

Виокремлено ключові відмінності у врегулюванні низки питань між положеннями Бернської конвенції про охорону літературних i художніх творів та Всесвітньої конвенціі про авторське право. Серед останніх відзначено, зокрема, розбінності у визначенні строку охорони літературних $i$ художніх творів та порядку набуття правової охорони. До того ж у статті наголошено на тому, що, на відміну від Бернської конвен- ціï, яка містить низку спеціальних положень, присвячених врегулюванню порядку реалізації та захисту авторських прав на кінотвір, Всесвітня конвенція про авторське право обмежується лише визнанням останнього як об'єкта охорони.

Ключові слова: кінематографічний твір, авторські права, міжнародні стандарти охорони авторських прав, Бернська конвенція про охорону літературних і художніх творів, Всесвітня конвенція про авторське право.

Lubchuk O. Berne Convention for the Protection of Literary and Artistic Works and the Universal Copyright Convention

The article reveals the main aspects of copyright protection for a cinematographic work based on an analysis of the provisions of the Berne Convention for the Protection of Literary and Artistic Works and the Universal Copyright Convention. It is noteworthy that it was the Berne Convention that laid the foundations of the international system of copyright protection for films by including the latter in the list of copyright objects following the results of the Berlin Conference in 1908. It is noted that not only the basic principles of the Convention can be applied to cinematographic works, but also a number of special provisions that directly address the protection of the latter. Thus, the peculiarities of the legal regime of a cinematographic work are taken into account when regulating such issues as: the term of protection of a cinematographic work; the procedure for determining the persons endowed with copyright to it; the procedure for transferring authors' rights to a cinematographic work to its producer etc.

It is noted that, due to the high level of minimum protection established by the Berne Convention as compared to the relevant national legislations, it has long remained unacceptable for a 
number of countries. As a result, the Universal Copyright Convention was adopted at the Intergovernmental Conference in Geneva in September 1952 in order to provide the necessary preconditions for further expansion of international co-operation in the field of copyright protection.

The key differences in the settlement of a number of issues between the provisions of the Berne Convention for the Protection of Literary and Artistic Works and the Universal Copyright Convention are highlighted. Among them are differences in determining the term of protection of literary and artistic works and the procedure for acquiring legal protection. In addition, it is emphasized that, unlike the Berne Convention, which contains a number of special provisions on the regulation and protection of copyright in a cinematographic work, the Universal Copyright Convention is limited to recognizing the latter as an object of protection.

Key words: cinematographic work, copyright, international standards of copyright protection, the Berne Convention for the Protection of Literary and Artistic Works, the Universal Copyright Convention.

\footnotetext{
Література

1. Бернська конвенція про охорону літературних $i$ художніх творів. URL: http://zakon.rada.gov.ua/laws / show/995_051.

2. Про приєднання України до Бернської конвенції про охорону літературних i художніх творів (Паризького акта від 24 липня 1971 року, зміненого 2 жовтня 1979 року) : Закон України від 31 травня 1995 року № 189/95-ВР. Відомості Вер-
}

ховної Ради України. 1995. № 21. Ст. 155.

3. Дахно I.I. Право інтелектуальної власності : навчальний посібник. 2-ге вид., перероб. $i$ доп. Київ : Центр навчальної літератури, 2006. 278 c.

4. Ромашин Э.С. Особенности правовой охраны аудиовизуального произведения как сложного комплексного объекта интеллектуальной собственности дисс. ... канд. юрид. наук : спец. 12.00.03. Москва, 2016. 170 с.

5. Дроб'язко В.C. Історичні й теоретичні аспекти Бернської конвенції про охорону літературних $i$ художніх творів : монографія. Київ : НДІ інтелектуальної власності НАПрНУ ; Iнтерсервіс, 2018. 124 с.

6. Близнеи И.А., Леонтьев К.Б. Авторское право и смежные права: учебник. Москва : Проспект, 2014. 374 c. URL: https: / / books.google.com.ua/ books?id=FCD9AgAAQBAJ\&pg.

7. Дроб'язко В.С. Всесвітня конвениія про авторське право 1971 року. Теорія i практика інтелектуальної власності. 2017. № 3. C. 27-31.

8. Всесвітня конвенція про авторське nраво. URL: https: / / zakon.rada.gov.ua/ laws/show/995_052.

9. Про участь України у Всесвітній конвенції про авторське право 1952 року : Постанова Верховної Ради України. Відомості Верховної Ради України. 1994. № 13. Cm. 70 .

10. Вахонева T.м. Вплив міжнародного права на формування та правову охорону авторських $i$ суміжних прав в Україні. Альманах міннародного права. 2016. Bun. 11. C. 12-22.

11. Коваленко T.О. 3 історіі розвитку міжнародного законодавства щодо захисту авторського права. Теорія i практика інтелектуальної власності. 2013. № 3. C. 35-43.

12. Афанасьєва К.О. Авторське право : практичне посібник. Київ: Атіка, 2006. 224 c. 